\title{
Pre-lysis washing improves DNA extraction from a forest soil
}

\author{
Jizheng $\mathrm{He}^{\mathrm{b}, *}$, Zhihong $\mathrm{Xu}^{\mathrm{a}}$, Jane Hughes ${ }^{\mathrm{a}}$ \\ ${ }^{a}$ Co-operative Research Centre (CRC) for Sustainable Production Forestry and Australian School of Environmental Studies, \\ Faculty of Environmental Sciences, Griffith University, Nathan, Qld 4111, Australia \\ ${ }^{\mathrm{b}}$ Research Centre for Eco-environmental Sciences, Chinese Academy of Sciences, Beijing 100085, China
}

Received 21 December 2004; received in revised form 11 April 2005; accepted 13 April 2005

\begin{abstract}
A pre-lysis buffer washing procedure was introduced to DNA extraction from a forest soil with high organic matter and iron oxide contents. Sodium phosphate of $0.1 \mathrm{M}$ (pH 7.5) was used as a buffer to wash soil samples when subsequent lysis buffer was phosphate, and $20 \mathrm{mM}$ EDTA (pH 7.5) was used when subsequent lysis buffer included EDTA. Initial experiments were not successful because the DNA extracts could not be amplified by polymerase chain reaction (PCR). The consideration of introducing a pre-lysis washing procedure was based on the idea that the washing should promote soil dispersion and homogeneity, decrease DNA adsorption by soil components (e.g. iron oxides), and remove covalent cations and those easily-dissolving organic compounds from the soil samples. Results revealed that humic substance content decreased by $31 \%$, but DNA yield increased by $24 \%$ in the DNA extracts of the pre-lysis washing procedures, compared to the non-washing procedures. DNA extracted by the pre-washing procedure needed less purification for subsequent $18 \mathrm{~S}$ and $16 \mathrm{~S}$ rDNA PCR amplifications. It was recommended that the pre-lysis buffer washing should be used for DNA extraction from those difficult environmental samples, such as the forest soil with high contents of organic matter and iron oxides.
\end{abstract}

(C) 2005 Elsevier Ltd. All rights reserved.

Keywords: DNA extraction; Buffer washing; Forest soil; Humic substance; Iron oxides; Polymerase chain reaction

DNA-based molecular microbiological study relies heavily on methods of DNA extraction from environmental samples with complex composition. However, the extraction of DNA from difficult environmental samples, such as soil with high organic matter content, has not been easy (Ogram, 2000). A large number of methods for DNA extraction from soil and sediment samples have been developed over the past two decades (e.g. Ogram et al., 1987; Holben et al., 1988; Tsai and Olson, 1991; Zhou et al., 1996; Krsek and Wellington, 1999; Miller et al., 1999; Griffiths et al., 2000; Bürgmann et al., 2001). All these methods are of two types, i.e. cell extraction and direct lysis. Cell extraction is based on the isolation of microbial cells from soils, prior to lysis to release microbial DNA.

\footnotetext{
* Corresponding author. Address: Co-operative Research Centre (CRC) for Sustainable Production Forestry and Australian School of Environmental Studies, Faculty of Environmental Sciences, Griffith University, Nathan, Qld 4111, Australia. Tel.: +86106284 9788; fax: +86106292 3563 .

E-mail address: j.he@griffith.edu.au (J. He).
}

0038-0717/\$ - see front matter (C) 2005 Elsevier Ltd. All rights reserved. doi:10.1016/j.soilbio.2005.04.016
It extracts purer DNA from soil matrix (Torsvik, 1980; Holben et al., 1988; Holben, 1994). Direct lysis method directly lyses microbial cells in soil-buffer paste and then separates DNA from the mixture (Ogram et al., 1987; Tsai and Olson, 1991; Zhou et al., 1996; Griffiths et al., 2000). It typically yields higher amounts of DNA, but also extracts much more humic substances than the cell extraction (Ogram, 2000). Intensive subsequent purification of DNA extracts from the direct lysis is needed, but substantial DNA in the extracts could be lost (Miller et al., 1999; RooseAmsaleg et al., 2001). The cell lysis buffers, such as $0.12 \mathrm{M}$ sodium phosphate ( $\mathrm{pH}$ 8.0) (Ogram et al., 1987), TE buffer (10 mM Tris-HCl/1 mM EDTA, pH 8.0), $1 \mathrm{mM}$ sodium phosphate (pH 7.0) (Holben, 1994), and $100 \mathrm{mM}$ Tris-HCl/ EDTA/sodium phosphate mixture (pH 8.0) (Zhou et al., 1996), could also be divided into two groups, i.e. Tris-HCl/ EDTA and phosphate with $\mathrm{pH}$ 7.0-8.0.

At the initial stage of this study, we tried four soil DNA extraction methods, i.e. the method described by Holben (1994), the method developed by Zhou et al. (1996), and two commercial kits of FastDNA ${ }^{\circledR}$ and UltraClean ${ }^{\mathrm{TM}}$. However, probably owing to the high organic matter and iron oxide contents of the forest soil samples, the DNA 
extracts were dark in color and PCR amplification was minimal. Thus, a hypothesis was proposed that pre-lysis buffer washing would remove those co-extractable contaminants (e.g. humic acids) and thus improve the PCR amplification of the DNA extracts. The hypothesis was based on the idea that the buffer washing would promote soil dispersion and homogeneity, decrease DNA adsorption by soil components (e.g. iron oxides), and remove covalent cations and those easily-dissolving organic compounds from the soil samples. Three washing buffers $(\mathrm{pH} 7.5)$, i.e. $1 \%$ sodium hexametaphosphate (HMP) which is extensively used for soil dispersion such as in soil particle analysis, $0.1 \mathrm{M}$ sodium phosphate, and $20 \mathrm{mM}$ EDTA, were selected. The latter two are usually the major components of the cell lysis buffers. Anions of phosphate and EDTA are able to compete for adsorption sites with DNA and extract covalent cations and trace metals. The concentrations of the washing buffers were adjusted according to soil cation exchange capacity (CEC) to ensure their capability in soil dispersion and extraction of cations and organic matter. It was expected that the pre-lysis washing procedure would highlight some advantages of both the cell extraction (i.e. minimizing co-extractable humic substances) and the direct lysis (i.e. it is still a direct lysis method).

Three surface soil samples used in this study were collected at the natural forest (YNF), first rotation (Y1R) and second rotation (Y2R) hoop pine (Araucaria cunninghamii) plantation sites of the Yarraman State Forest, Queensland, Australia $\left(26^{\circ} 52^{\prime} \mathrm{S}, 151^{\circ} 51^{\prime} \mathrm{E}\right)$. The soil is a Snuffy Mesotrophic Red Ferrosol (Isbell, 1996) with a clay-loamy A1 horizon, and a clayey B horizon (free iron oxide content greater than $5 \% \mathrm{Fe}$ in the fine earth fraction). The samples have high organic matter contents ranging from 10 to $11 \%$ and clay contents from 36.0 to $48.4 \%$.

The soil samples of $5.0 \mathrm{~g}$ and $25 \mathrm{ml}$ washing buffer were mixed and gently shaken for $1 \mathrm{~h}$ in an Orbital Mixer Incubator (Ratek, Australia) at room temperature, centrifuged at $16,000 \mathrm{~g}$ for $10 \mathrm{~min}$, and the supernatants were collected. The concentration of organic substances in the supernatants was estimated from the absorbance at $230 \mathrm{~nm}$ (A230) compared with the humic substance standards (International Humic Substances Society, Minnesota, USA) by spectrophotometric analysis. The remnants were then extracted using Holben's method (Holben, 1994), Zhou's method (Zhou et al., 1996), FastDNA ${ }^{\circledR}$ and UltraClean ${ }^{\mathrm{TM}}$ kits. Briefly, for the Holben's extraction, the pre-washed samples were washed again with $1 \mathrm{mM}$ sodium phosphate lysis buffer (pH 8.0), and 5.0 g glass beads, $0.15 \mathrm{~g}$ sodium dodecyl sulfate (SDS) and $15 \mathrm{ml}$ lysis buffer were added. The mixtures were incubated for $1 \mathrm{~h}$ in a $65^{\circ} \mathrm{C}$ water bath, shaken for $30 \mathrm{~min}$ at a speed of $250 \mathrm{rpm}$, and then centrifuged at $8000 \mathrm{~g}$ for $15 \mathrm{~min}$. The supernatants were collected to isolate DNA as described below. For the Zhou's extraction, the pre-washed samples were washed again with Zhou's lysis buffer (100 mM Tris-HCl/100 mM EDTA [pH 8.0], $100 \mathrm{mM}$ sodium phosphate [pH 8.0], $1.5 \mathrm{M} \mathrm{NaCl}$,
$1 \% \mathrm{CTAB}$ ), and the lysis buffer was supplemented to $13.5 \mathrm{ml}$ and $0.1 \mathrm{ml}$ proteinase $\mathrm{K}\left(10 \mathrm{mg} \mathrm{ml}^{-1}\right)$ was added. The mixtures were simply vortexed and horizontally shaken at $225 \mathrm{rpm}$ for $30 \mathrm{~min}$ at $37^{\circ} \mathrm{C}$. Then $1.5 \mathrm{ml}$ of $20 \%$ SDS was added, and the samples were incubated for $1 \mathrm{~h}$ in a $65{ }^{\circ} \mathrm{C}$ water bath with end-over-end inversions and centrifuged at $8000 \mathrm{~g}$ for $15 \mathrm{~min}$. The supernatants were collected to isolate DNA as described below.

The above supernatants after SDS precipitation were extracted with equal volumes $(10 \mathrm{ml})$ of phenol-chloroform-isoamyl alcohol (25:24:1, by vol.) and then with chloroform-isoamyl alcohol (24:1, vol/vol). The aqueous phase was recovered by centrifugation and precipitated with 0.6 volume of cold isopropanol. The pellet of crude DNA was obtained by centrifugation at $16,000 \mathrm{~g}$ for $20 \mathrm{~min}$ at $2{ }^{\circ} \mathrm{C}$, washed with cold $70 \%$ ethanol, and re-suspended in sterile TE buffer. The crude DNA suspensions were kept at $4{ }^{\circ} \mathrm{C}$ for further spectrophotometric analysis, purification and quantitation. The purification procedures were developed from Krsek and Wellington (1999), including two assemblages: (1) $15 \mathrm{~min}$ incubation with one-fifth volume of $8 \mathrm{M}$ potassium acetate (KAc) on ice, and then phenol/ chloroform purification; and (2) acid washed polyvinylpolypyrrolidone (PVPP) spin column followed by a second spin column with Sephadex ${ }^{\mathrm{TM}}$ G150. DNA extractions using FastDNA $^{\circledR}$ and UltraClean ${ }^{\mathrm{TM}}$ kits were carried out according to the manufacturers instructions, using $0.5 \mathrm{~g}$ samples pre-washed with $0.1 \mathrm{M}$ sodium phosphate. These two methods employed bead-beating lysis and spin filter purification. However, for the UltraClean, an alternative lysis method was selected, i.e. the vortexing and heating procedure as described in the manufacturer's instruction, which would reduce shearing but may reduce yield. The extracted DNA size and yield were estimated by comparing with standards on $1 \%$ agarose gels. The gels were stained in ethidium bromide $\left(0.5 \mathrm{mg}^{-1}\right)$ and visualized under UV light. Automated quantification was achieved by comparing the fluorescence intensities of the samples to DNA standards using the BIO-RAD GelDoc System 2000.

PCR amplification of the extracted DNA was carried out using an Eppendorf Mastercycler. Annealing temperatures of the PCR reaction were selected based on data from the literature and experiments using a touch down (temperature gradient) program to achieve better PCR products band on subsequent agarose gel analysis (Table 4). The volume of the reaction mixtures was $50 \mu \mathrm{l}$, which usually contained $1 \times$ PCR buffer, $5 \mathrm{mM} \mathrm{MgCl} 2,2 \mathrm{mM}$ dNTP's, $2.5 \mathrm{U}$ Taq polymerase from GibcoBRL (for $18 \mathrm{~S}$ rDNA) and from QIAGEN (for $16 \mathrm{~S}$ rDNA), $0.3 \mu \mathrm{M}$ each of primers, and 1 or $2 \mu$ DNA templates of the purified or diluted DNA extracts. Thirty cycles were run depending on reaction conditions. For example, for $18 \mathrm{~S}$ rDNA amplification using fungalspecific primers of Ef4f (GGA AGG G[G/A]T GTA TTT ATT AG) and Fung5r (GTA AAA GTC CTG GTT CCC) (van Elsas et al., 2000), the thermal cycling scheme was heated to $94{ }^{\circ} \mathrm{C}$ for $3 \mathrm{~min}$; then 30 cycles were run at $94{ }^{\circ} \mathrm{C}$ 
for $1 \mathrm{~min}, 55^{\circ} \mathrm{C}$ for $1 \mathrm{~min}$, and $72{ }^{\circ} \mathrm{C}$ for $2 \mathrm{~min}$; and finally $72{ }^{\circ} \mathrm{C}$ for $10 \mathrm{~min}$. For $16 \mathrm{~S}$ rDNA amplification using universal bacterial primers of P1 (CCT ACG GGA GGC AGC AG) and P3 (CCG TCA ATT CCT TTG AGT TT) (Krsek and Wellington, 1999), the thermal cycling scheme was heated to $94{ }^{\circ} \mathrm{C}$ for $7 \mathrm{~min}$; then 30 cycles were run at $94{ }^{\circ} \mathrm{C}$ for $1 \mathrm{~min}, 60^{\circ} \mathrm{C}$ for $1 \mathrm{~min}$, and $72{ }^{\circ} \mathrm{C}$ for $2 \mathrm{~min}$; and finally $72{ }^{\circ} \mathrm{C}$ for $10 \mathrm{~min}$.

Results showed that the pre-lysis buffer washing removed humic substances from the samples (Table 1). One percentage of sodium HMP, $0.1 \mathrm{M}$ sodium phosphate and $20 \mathrm{mM}$ EDTA removed $0.9,1.1$ and $1.3 \mathrm{~g}$ humic substances $\mathrm{kg}^{-1}$ soil, respectively, accounted for about $1 \%$ of the total organic matter content of the samples. Owing to the strong dispersion power of HMP, the subsequent centrifugation after the washing was more difficult to obtain the clear supernatants. Moreover, HMP washing removed less amount of organic matter than the other two buffers, but it introduced a new chemical (i.e. HMP) to the subsequent DNA extraction process. Therefore, HMP is not recommended as a pre-lysis washing solution for the soil DNA extraction. On the other hand, $0.1 \mathrm{M}$ sodium phosphate and $20 \mathrm{mM}$ EDTA washing removed more humic substances and did not introduce any new chemical to the lysis buffer. Thus, they were used as the pre-lysis washing buffer when subsequent lysis buffer included phosphate and EDTA, respectively, and only the results using these two washing procedures were reported below.

The extracted DNA sizes by the Zhou's and Holben's methods with or without the pre-lysis washing were all about $20 \mathrm{~kb}$ (data not shown), revealing that these methods did not cause severe DNA shearing and the washing did not result in the change in the DNA sizes. However, comparing the effect of washing on the amount of humic substances in the crude DNA extracts (Table 2), for Zhou's extraction, the washing extracted 98,93 and $80{\mu \mathrm{g} \mathrm{g}^{-1}}$ soil less humic substances than the non-washing procedure, which accounted for 34, 26 and $36 \%$ of the humic substances extracted by the non-washing procedure for YNF, Y1R and Y2R samples, respectively. Pre-lysis washing with $0.1 \mathrm{M}$ phosphate also decreased humic substances in the DNA extracts of the Holben's method, by decreasing 36, 24 and $31 \%$ for YNF, Y1R and Y2R samples, respectively.

Table 1

Humic substances amount $\left(\mathrm{g} \mathrm{kg}^{-1}\right.$ soil) (mean $\left.\pm \mathrm{SD}, n=4\right)$ extracted by pre-lysis washing buffers from three soil samples of Yarraman natural forest (YNF) and the first (Y1R) and second (Y2R) rotation of hoop pine plantations

\begin{tabular}{llll}
\hline Washing buffer & YNF & Y1R & Y2R \\
\hline $\begin{array}{l}\text { 1\% sodium } \\
\text { hexametapho- } \\
\text { sphate }\end{array}$ & $0.93 \pm 0.03$ & $0.95 \pm 0.05$ & $0.90 \pm 0.03$ \\
$\begin{array}{l}0.1 \text { M sodium } \\
\text { phosphate }\end{array}$ & $1.10 \pm 0.03$ & $1.10 \pm 0.04$ & $1.08 \pm 0.04$ \\
20 mM EDTA & $1.28 \pm 0.08$ & $1.31 \pm 0.10$ & $1.25 \pm 0.06$ \\
\hline
\end{tabular}

Table 2

Humic substances (HS) contents ( $\mu \mathrm{g} \mathrm{g}^{-1}$ soil) (mean $\left.\pm \mathrm{SD}, n=2\right)$ in the DNA extracts obtained from the Zhou's and Holben's methods with (-W) and without (-NW) the pre-lysis washing procedures

\begin{tabular}{|c|c|c|c|c|c|c|}
\hline \multirow[t]{2}{*}{ Sample } & \multicolumn{2}{|l|}{$\begin{array}{l}\text { Method } \\
\text { YNF }\end{array}$} & \multicolumn{2}{|l|}{ Y1R } & \multicolumn{2}{|l|}{ Y2R } \\
\hline & Holben & Zhou & Holben & Zhou & Holben & Zhou \\
\hline HS-W & $87 \pm 12$ & $189 \pm 21$ & $136 \pm 19$ & $265 \pm 39$ & $66 \pm 11$ & $145 \pm 23$ \\
\hline HS-NW & $135 \pm 25$ & $287 \pm 46$ & $176 \pm 22$ & $358 \pm 51$ & $96 \pm 16$ & $225 \pm 40$ \\
\hline $\begin{array}{l}\text { HS-NW- } \\
\text { HS-W }\end{array}$ & 48 & 98 & 40 & 93 & 30 & 80 \\
\hline
\end{tabular}

On average, the pre-lysis washing procedures decreased humic substances in the DNA extracts by $31 \pm 5 \%$ compared with the non-washing procedures. On the other hand, the pre-lysis washing procedures increased DNA concentrations in the extracts (Table 3). Compared with the non-washing procedure, the washing procedure extracted 12-20 $\mathrm{g} \mathrm{g}^{-1}$ soil more DNA for Zhou's method and 8-12 $\mu \mathrm{g} \mathrm{g}^{-1}$ soil more DNA for Holben's method, which accounted for $16-30 \%(23.8 \pm 5.2 \%)$ more than the nonwashing procedure. It can be seen that the pre-lysis washing is effective in decreasing co-extracted humic substances and increasing DNA yield in the DNA extracts. Therefore, the pre-lysis washing step is recommended for those difficult environmental samples, such as those with high organic matter contents. The FastDNA kits extracted more DNA than the UltraClean, Holben's and Zhou's methods (Table 3), probably due to its more vigorous lysis procedure (continuously $30 \mathrm{~s}$ lysis on the FastPrep instrument).

PCR amplification was not successful with the crude DNA extracted by the non-washing Zhou's and Holben's procedures, even though the crude DNA was diluted $10^{4}$-fold. However, when the crude DNA was extracted with pre-washing and Holben's procedure, $10^{2}$ dilution produced some PCR products at the predicted sizes. DNA extracts of the washing and Zhou's method did not produce PCR products, even diluted to $10^{4}$-fold, probably because it still extracted more humic substances than Holben's method (Table 2). For the washing and nonwashing DNA extracts, PCR amplification results by different extraction and purification methods were compared using different primer pairs (Table 4). Overall, DNA

Table 3

Crude DNA yield ( $\mathrm{\mu g} \mathrm{g}^{-1}$ soil) extracted by modified Holben, Zhou, FastDNA and UltraClean methods with (-W) and without (-NW) the prelysis washing procedures

\begin{tabular}{lllll}
\hline Sample & $\begin{array}{l}\text { Method } \\
\text { Holben }\end{array}$ & Zhou & FastDNA & UltraClean \\
\hline YNF-W & 64 & 87 & 96 & 58 \\
YNF-NW & 52 & 67 & ND & ND \\
Y1R-W & 58 & 68 & 89 & 52 \\
Y1R-NW & 50 & 56 & ND & ND \\
Y2R-W & 48 & 57 & 85 & 55 \\
Y2R-NW & 39 & 44 & ND & ND \\
\hline
\end{tabular}


Table 4

PCR results using the DNA extracted by the pre-lysis buffer washing and the Zhou's extraction and the Holben's extraction (results in the parentheses), and purified by 1 -KAc precipitation and phenol/chloroform purification or 2-PVPP and Sephadex spin columns purification

\begin{tabular}{|c|c|c|c|c|c|}
\hline \multirow[t]{2}{*}{ Primer pairs } & \multirow{2}{*}{$\begin{array}{l}\text { Annealing } \\
\text { temperature }\left({ }^{\circ} \mathrm{C}\right)\end{array}$} & \multirow[t]{2}{*}{ Product length (bp) } & \multicolumn{2}{|l|}{ Product effect } & \multirow[t]{2}{*}{ Reference } \\
\hline & & & Purification 1 & Purification 2 & \\
\hline $\mathrm{P} 1(341 \mathrm{~F})-\mathrm{P} 2(534 \mathrm{R})$ & 64 & 200 & $++(0)$ & $+(+)$ & Krsek and Wellington (1999) \\
\hline P1(341F)-P3(907R) & 54 & 560 & $++(++)$ & $++(+)$ & Krsek and Wellington (1999) \\
\hline P4(984F)-P5(1378R) & 54 & 430 & $++(+)$ & $++(0)$ & Krsek and Wellington (1999) \\
\hline $\operatorname{Ps}(292 \mathrm{~F})-\operatorname{Com} 2(907 R)$ & 65 & 630 & $++(0)$ & $+(+)$ & Stach et al. (2001)) \\
\hline EF4f-Fung5r & 55 & 550 & $+(++)$ & $0(++)$ & van Elsas et al. (2000) \\
\hline EF4f-NS2r & 48 & 340 & $0(++)$ & $+(++)$ & van Elsas et al. (2000) \\
\hline
\end{tabular}

PCR product effect: 0 , very weak or no product band; + , weak product band; ++ , strong product band.

extracted by the pre-washing procedure achieved better PCR amplification than that by the non-washing procedure under the same purification conditions. KAc precipitation plus phenol/chloroform purification, and PVPP and Sepha$\operatorname{dex}^{\mathrm{TM}}$ G150 spin columns purification achieved good PCR results for all extractions. The purified products by these two purification methods can be directly used for PCR amplification and the results are listed in Table 4. For the 18S rDNA PCR amplification using fungal-specific primers, Holben's extraction achieved strong PCR products but Zhou's extraction achieved weak or no product (Fig. 1). On the other hand, DNA extracts by Zhou's method achieved strong bands for $16 \mathrm{~S}$ rDNA amplification by bacterialspecific primer pairs of P1-P3 and P4-P5. The advantage of Holben's method over Zhou's method in extracting fungal DNA may be attributed to its bead mill, which is usually needed to crush fungal cells (van Elsas et al., 2000). Moreover, it may also be attributed to less humic substances in the Holben's DNA extracts than in the Zhou's DNA extracts. The DNA extracted by the UltraClean and the FastDNA kits with the pre-washing procedure were successfully PCR amplified after 100-fold dilution using all the primer pairs listed in Table 4.

DNA extraction is a physico-chemical process during which some compounds may be co-extracted, such as humic acids, and inhibit subsequent PCR amplification (Wilson, 1997) and cause bias in microbial community analyses (Frostegard et al., 1999; Miller et al., 1999; Martin-Laurent et al., 2001). However, there is little information about the inhibitory compounds in the DNA extracts although most studies have supposed or implied that they are humic acids

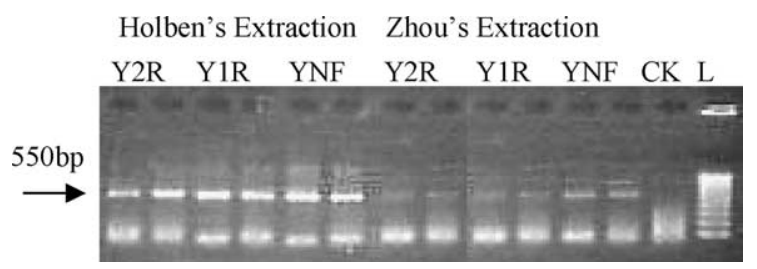

Fig. 1. 18S rDNA PCR amplification with fungal-specific EF4f-Fung5r primers. DNA was purified by KAc precipitation and phenol/chloroform purification. L-100 bp ladder; and CK-Negative control.
(Tebbe and Vahjen, 1993; Bürgmann et al., 2001; MartinLaurent et al., 2001). During DNA extraction processes, not much attention was paid to the very complex soil components, which include a series of organic and inorganic substances, from low-molecular-weight organic acid (e.g. oxalic acid) to macromolecular humic acids, and from cations (e.g. $\mathrm{Na}^{+}, \mathrm{K}^{+}$and $\mathrm{Al}^{3+}$ ) to anions (e.g. $\mathrm{NO}_{3}^{-}, \mathrm{Cl}^{-}$, phosphate and organic anions). These components could be co-extracted with DNA and also interacted with DNA and thus influence DNA isolation from soil and subsequent DNA-based molecular analyses. One of the advantages of the introduced pre-lysis washing by the lysis buffer is that it removed substantial humic substances and also some other compounds, such as trace metals which are extractable by EDTA from the soil samples, and thus prevented them being involved in the cell lysis and subsequent steps. Moreover, the pre-washing procedure is simple and easy to operate. Therefore, it is strongly recommended for DNA extraction from those complicated and difficult environmental samples, such as soil with high content of organic matter.

Some microbes and extracellular DNA may be lost from the pre-lysis washing. We set the centrifugation force at $16,000 \mathrm{~g}$ for $10 \mathrm{~min}$ in the pre-lysis washing procedure to minimize the microbial cell loss. This centrifugation force, even the lower forces (e.g. 10,000g), were widely used to isolate microbial cells and DNA from supernatants (e.g. Ogram et al., 1987; Tsai and Olson, 1991; Holben, 1994; Zhou et al., 1996). Moreover, the pre-lysis washing resulted in a higher yield of microbial DNA extracted. Therefore, the microbial cell and DNA loss from the pre-lysis washing should not be a big issue. However, the effects of DNA extraction with and without the pre-lysis washing procedures on soil microbial profile analyses may need to be elucidated from a wider range of soil samples, and thus deserves further investigation.

\section{Acknowledgements}

The funding support from Griffith University, Cooperative Research Centre for Sustainable Production Forestry, Australian Research Council, and Queensland Department 
of Primary Industries-Forestry, is acknowledged. We are grateful to Jing Ma from the Molecular Ecology Laboratory of Griffith University for her technical assistance.

\section{References}

Bürgmann, H., Pesaro, M., Widmer, F., Zeyer, J., 2001. A strategy for optimizing quality and quantity of DNA extracted from soil. Journal of Microbiological Methods 45, 7-20.

Frostegard, A., Courtois, S., Ramisse, V., Clerc, S., Bernillon, D., Le Gall, F., Jeannin, P., Nesme, X., Simonet, P., 1999. Quantification of bias related to the extraction of DNA directly from soils. Applied and Environmental Microbiology 65, 5409-5420.

Griffiths, R.I., Whiteley, A.S., O'Donnell, A.G., Bailey, M.J., 2000. Rapid method for coextraction of DNA and RNA from natural environments for analysis of ribosomal DNA- and rRNA-based microbial community composition. Applied and Environmental Microbiology 66, 5488-5491.

Holben, W.E., 1994. Isolation and purification of bacterial DNA from soil. In: Weawer, R.W. (Ed.), Methods of Soil Analysis. Part 2. Microbiological and Biochemical Properties. Soil Science Society of America, Madison, WI, pp. 727-751.

Holben, W.E., Jansson, J.K., Chelm, B.K., Tiedje, J.M., 1988. DNA probe method for the detection of specific microorganisms in the soil bacterial community. Applied and Environmental Microbiology 54, 703-711.

Isbell, R.F., 1996. The Australian Soil Classification. CSIRO Publishing, Melbourne, Australia. 143pp.

Krsek, M., Wellington, E.M.H., 1999. Comparison of different methods for the isolation and purification of total community DNA from soil. Journal of Microbiological Methods 39, 1-16.

Martin-Laurent, F., Philippot, L., Hallet, S., Chaussod, R., Germon, J.C., Soulas, G., Catroux, G., 2001. DNA extraction from soils: old bias for new microbial diversity analysis methods. Applied and Environmental Microbiology 67, 2354-2359.
Miller, D.N., Bryant, J.E., Madsen, E.L., Ghiorse, W.C., 1999. Evaluation and optimization of DNA extraction and purification procedures for soil and sediment samples. Applied and Environmental Microbiology 65, 4715-4724.

Ogram, A., 2000. Soil molecular microbial ecology at age 20: methodological challenges for the future. Soil Biology \& Biochemistry 32, 1499-1504.

Ogram, A., Sayler, G.S., Barkay, T., 1987. The extraction and purification of microbial DNA from sediments. Journal of Microbiological Methods 7, 57-66.

Roose-Amsaleg, C.L., Garnier-Sillam, E., Harry, M., 2001. Extraction and purification of microbial DNA from soil and sediment samples. Applied Soil Ecology 18, 47-60.

Stach, J.E.M., Bathe, S., Clapp, J.P., Burns, R.G., 2001. PCR-SSCP comparison of $16 \mathrm{~S}$ rDNA sequence diversity in soil DNA obtained using different isolation and purification methods. FEMS Microbiology Ecology 36, 139-151.

Tebbe, C., Vahjen, W., 1993. Interference of humic acids and DNA extracted directly from soil in detection and transformation of recombinant DNA from bacteria and a yeast. Applied and Environmental Microbiology 59, 2657-2665.

Torsvik, V.L., 1980. Isolation of bacterial DNA from soil. Soil Biology \& Biochemistry 12, 15-21.

Tsai, Y., Olson, B., 1991. Rapid method for separation of bacterial DNA from humic substances in sediments for polymerase chain reaction. Applied and Environmental Microbiology 58, 2292-2295.

van Elsas, J.D., Duarte, G.F., Keijzer-Wolters, A., Smit, E., 2000. Analysis of the dynamics of fungal communities in soil via fungal-specific PCR of soil DNA followed by denaturing gradient gel electrophoresis. Journal of Microbiological Methods 43, 133-151.

Wilson, I.G., 1997. Inhibition and facilitation of nucleic acid amplification. Applied and Environmental Microbiology 63, 37413751.

Zhou, J., Bruns, M., Tiedje, J.M., 1996. DNA recovery from soils of diverse composition. Applied and Environmental Microbiology 62, 316-322. 